\title{
Need for security and system fairness on the political extremes
}

\author{
Hulda Pórisdóttir, Assistant Professor of Political Science, University of \\ Iceland
}

Eva H. Önnudóttir, Postdoctoral Scholar in Political Science, University of Iceland

\begin{abstract}
We advance and empirically test the idea that people on both the far right and far left will be more likely than political moderates to perceive the system as fair, as long as it serves their heightened needs for security. We argue that political extremists may be especially drawn to systems that offer certainty and security. As long as ideological extremists are not alienated from the political system in general, they will, therefore, be especially motivated to see the system as fair, in particular, if extremism is coupled with a heightened need for security. We test this notion using data from Iceland, a country with a wide left-right spread in terms of the political opinions of both parties and people and which was, at the time of the study, still reeling from an economic crisis that strongly affected political trust and threatened people's sense of security. We analyzed nationally representative data from the European Social Survey in $2012(\mathrm{~N}=752)$. The results showed a significant three-way interaction between political extremism, the need for security, and political trust in predicting perceived system fairness. The people most likely to perceive the system as fair were political extremists, with relatively high political trust and need for security. The results are discussed in light of context effects and how people on the left and right might have higher needs for security with different threats in mind.
\end{abstract}

Keywords: system fairness; left-right extremism; need for security; political trust.

\footnotetext{
Icelandic Review of Politics and Administration Vol. 11, Issue 2 (115-138)

(c) 2015 Contact: Hulda Pórisdóttir, huldat@hi.is

Article first published online December 17th 2015 on http://www.irpa.is

Publisher: Institute of Public Administration and Politics, Gimli, Sæmundargötu 1, 101 Reykjavík, Iceland

Stjórnmál \& stjórnsýsla 2. tbl. 11. árg. 2015 (115-138) Fræđigreinar

(c) 2015 Tengiliður: Hulda Pórisdóttir, huldat@hi.is

Vefbirting 17. desember 2015 - Birtist á vefnum http://www.irpa.is

Útgefandi: Stofnun stjórnsýslufræða og stjórnmála, Gimli, Sæmundargötu 1, 101 Reykjavík

DOI: http://dx.doi.org/10.13177/irpa.a.2015.11.2.1

This work is licensed under a Creative Commons Attribution 3.0 License.
} 


\section{Introduction}

People who explicitly embrace political ideology on the fringes of the political spectrum may have a complicated relationship with the general political system and authorities. Their relatively extreme political stance may be associated with detachment from the system, a system they perceive as far removed from their political vision. On the contrary, the adoption of an extreme ideology can be associated with a strong engagement with politics and the system. Those who explicitly define their political views on the extremes are likely to adhere to a well-defined political system, such as libertarianism or communism. Regardless of whether such political systems are to the left or the right, they are more likely than middle-ground compromises to offer clear and internally consistent ideological packages for what constitutes a fair and prosperous society. Such ideologies have been shown to be especially appealing to those who have relatively high needs to manage uncertainty and threat (van Prooijen, Krouwel, Boiten \& Eendbak 2015) and are linked to an illusion of understanding (Frenbach, Rogers, Fox \& Sloman 2013). When people embrace an ideology on the extremes, current governmental policies and decisions are typically not going to offer a good representation of their opinions and values. This is especially true in countries with coalition governments in which compromises between parties are unavoidable. The experience of what could be labeled representational exclusion is potentially troublesome for people who have a relatively high need for security and yet have not become alienated from the political system. System justification theory (Jost \& van der Toorn 2011) and the relational model of justice (Tyler \& Lind 1992) would predict that those people would be especially motivated to perceive authorities as fair and just. This is because, in this context, the system serves to meet their heightened needs for security.

In this research, using representative data from Icelandic voters, we advance and empirically test the idea that people on the political extremes will be more likely than political moderates to perceive the system as fair, as long as they are not alienated from the political system in general and it serves their heightened needs for security.

\section{Political ideology and the need for security}

A great deal of effort has gone into exploring how people on the political left and right differ from each other psychologically. Although the original work was done in the wake of World War II (Adorno, Frenkel-Brunswik, Levinson \& Sanford 1950), a 2003 meta-analysis and theoretical integration by Jost, Glaser, Kruglanski, and Sulloway revived the study of ideology. In the paper, they put forward the uncertainty threat model of political ideology that advanced the idea that people who embrace the conservative, or right-wing, ideology are motivated to do so in part because it serves their needs to manage their heightened sense of uncertainty and threat. The model was based on a review of 160 studies showing that various measures indicative of needs for order and structure, intolerance of ambiguity and uncertainty, low integrative complexity, and closed-mindedness correlated positively with scores on various scales that either measure or are closely related to political conservatism (Adorno et al. 1950; Altemeyer 1998; 
Jost \& Thompson 2000; Sidanius \& Pratto 1999; Wilson \& Patterson 1968), as well as with voting preferences and right-wing (vs. left-wing) self-placement. The uncertainty threat model ignited a great deal of interest in the topic, and researchers have continued to map psychological differences between conservatives and liberals, mostly confirming the model (Lammers \& Proulx 2013; Napier \& Jost 2008; Roccato, Vieno \& Russo 2013; Schlenker, Chambers \& Le 2012; van Lange, Bekkers, Chirumbolo \& Leone 2011).

Although the "rigidity of the right" idea has dominated research on the psychology of ideology, the question has also been asked whether the relationship between ideology and needs to manage uncertainty and threat is always monotonously linear. A study comparing the psychological predictors of the left-right ideology in several European countries found, for example, that "rigidity of the right" was not the rule in former Communist countries (Thorisdottir, Jost, Leviatan \& Shrout 2007). Malka and colleagues (Malka, Soto, Inzlicht \& Lelkes 2014) found that across 51 nations, the high need for security and certainty was related to both right-wing self-placement and cultural attitudes, but, conversely, slightly related to left-wing economic attitudes. More pertinent to the current research are studies showing a curvilinear relationship in which political extremism on both the right and left is related to experienced uncertainty and threat (Fernbach, Rogers, Fox \& Sloman 2013; van Prooijen, Krouwel, Boiten \& Eendebak 2015; Toner, Leary, Asher, \& Jongman-Sereno 2013)

An efficient way for people to reduce uncertainty is to root their beliefs and values in a world of consensus. This can be achieved by selectively exposing themselves primarily to people and information that share their view but also by subscribing to belief systems that are high in internal consistency. Political ideologies that are high in internal consistency are those that are clearly defined, comprehensive in scope, and often have (undisputed) authoritative texts or leaders. Such firm ideological convictions and belief systems that provide clear, comprehensive, and morally unambiguous political solutions are ideally suited to deal with feelings of uncertainty and fear, as they make the world more understandable and manageable (Hogg, Kruglanski \& Bos 2013; Kruglanski, Pierro, Mannetti \& De Grada 2006).

Due to their "purity," such ideologies tend to be associated with the political extremes, examples would be pure versions of libertarianism and communism. Along those lines is recent research demonstrating that political extremism is associated with believing in simple political solutions with clear rights and wrongs, cognitive rigidity, closed-mindedness, and a tendency for extremists to seek out information about politics from their in-group and ignore or reject other positions (Fernbach, Rogers, Fox \& Sloman 2013). This has led to the description of extremists as having a "crippled ideology" (Hardin 2002). Studies have also shown that, compared to moderates, political extremists are more susceptible to believing in conspiracy theories, which can at least be partially explained by their preference for simple solutions to societal problems (van Prooijen, Krouwel \& Pollet 2015).

Although political extremists are most frequently described as unthinking and rigid (McClosky \& Chong 1985; Tetlock 1986; Toner, Leary, Asher \& Jongman-Sereno 2013) 
with a lower capability for thinking integratively and a higher intolerance for ambiguity (McClosky \& Chong 1985), research also reveals another view of extremists (Brandt, Evans \& Crawford 2014). This other view contrasts with the first one and contends that political extremists are more engaged and sophisticated in their political knowledge and attitudes compared to moderates (Brandt, Evans \& Crawford 2014; Palfrey \& Poole 1987; Sidanius 1984, 1988; Sidanius \& Lau 1989; van Hiel \& Mervielde 2003; Zaller 1992).

This contrasting picture of political extremists in the literature probably indicates that people can be drawn to extremism for different reasons. Some, even the majority, are drawn toward extreme ideologies because they fulfill their need for certainty by offering an unambiguous and highly internally consistent belief system. Others, however, may arrive at their extreme political positions via other routes, possibly driven by dissatisfaction with the current state of politics. We would expect the latter to have a different relationship with authorities than the former, and this difference would be manifested in political trust.

\section{Political trust}

Political trust represents the degree to which people decide they can trust authorities not to abuse their power (Lühiste 2006). Psychologists define trust in authorities as based on beliefs and values, or "the belief that authority shares the members' fundamental values and will protect their interests" (De Cremer \& Tyler 2007, 640). Political trust can be viewed as increasingly wide-reaching circles, the innermost being trust in politicians, followed by trust in the political regime, and, finally, trust in the community at large (e.g., van Ham \& Thomassen 2014). Trust for the political community has been shown to be generally quite high and stable (e.g., Norris 2011), but other parts of political trust are highly influenced by whether authorities represent one's political opinion or not. Some scholars have even gone as far as to proclaim that political trust is solely driven by how much distance people see between themselves and the ruling parties (Newton 1999). In addition, the divide between trust for different actors and levels of the political system is not always clear. Fluctuations in political trust for the incumbents is generally not considered problematic given that this trust changes from one incumbent to the next. However, long-term low trust in incumbents could spill over to a lack of trust in political institutions and, thus, undermine the political system (van Ham \& Thomassen 2014). These concerns are due to the fact that trust in political institutions is generally considered to be more vital for the functioning of the political system and, specifically so, in democracies (Diamond 1999), and low trust for those indicates a need for system reform (van Ham \& Thomassen 2014).

Research has shown that low political trust is related to decreased voter turnout (Grönlund \& Setäl 2007) and that it is one of the main reasons people vote for extremist or populist parties (Hooghe, Marien \& Pauwels 2011). This, however, does not indicate that all extremists have low political trust. As discussed above, extremists may arrive at their extreme ideological stances for different reasons. Generalized dissatisfaction and 
lack of trust in the current political system may push some toward extreme ideologies, and these we would expect to feel alienated from the political system more generally and to be unlikely to see it as a source of security. Others, however, may be drawn to extreme ideologies because of the high internal consistency and certainty they offer. We would not expect this latter group to be especially distrustful of the political system. Research has shown trust to be correlated with judgments of the fairness of authorities, although the direction and nature of this relationship are not clear (De Cremer \& Tyler 2007).

\section{Procedural fairness of the system}

People judge the fairness of authority by two major standards: distributive fairness and procedural fairness. Decisions about distributive fairness are based on whether people find their outcomes to be fair, which is usually based on an equity norm and compared to what others receive (Tyler 2000). Meeting people's expectations for complete distributive justice can be difficult, if not impossible, because in addition to material resources usually being limited, people have a strong tendency to exaggerate their contributions to groups and, thus, how big their share of the outcome should be (Tyler 2000). Procedural fairness, however, is based on whether people see the decisions made by authorities as fairly decided upon (Tyler \& Lind 1992; Tyler 2000). A key characteristic of a fair procedure is that people are allowed to have a voice in the decision-making process. Other important characteristics are the perceived neutrality of the decision maker, transparency, and the view that people are treated with dignity and respect (Tyler 2000).

Although people care deeply about the fairness of their outcomes, research has demonstrated that fairness of procedures may be even more important for people's evaluation of authorities. Procedural fairness predicts, for example, people's willingness to obey and cooperate with authorities (Tyler 1990; Tyler \& Blader 2000; Tyler \& Huo 2002). The importance of procedural fairness is good news for authorities because a fundamental difference between distributive justice and procedural justice is that fair decision-making procedures is not a limited resource and that people are willing to accept unfavorable outcomes if they perceive that they were determined using fair procedures (e.g., van den Bos, Lind, Vermunt \& Wilke 1997). A relational model of procedural justice explains why procedural fairness matters to people (Tyler \& Lind 1992). According to the model, procedural justice is important because treatment by authorities conveys information about one's standing and respect within a social group. Procedural fairness thus offers assurance that one is both accepted and valued by a group, which can reduce uncertainty and offer security if the individual perceives the group as an important ingroup.

\section{Hypothesis}

Political extremists do not all have heightened security needs, but those who do will be especially motivated to perceive the political system as procedurally fair. This is not only because fair procedures tend to be predictable and, therefore, reduce the sense of uncertainty and offer security but also because high procedural fairness signals in-group 
respect and inclusion, which is perhaps particularly important to a political extremist with high needs for security. This, however, will only hold true for those political extremists who see the political system and its agents as their in-group. Extremists who are low on political trust presumably neither see the system as a potential source for security and certainty nor as an important in-group by which to be valued. Therefore, extremists with little political trust would not be motivated to perceive procedural justice as high.

We, therefore, hypothesize that an interaction will emerge between political extremism and the need for security in predicting perceived procedural fairness of the system. Extremists with a high need for security will be the most likely of all people to report high perceived procedural fairness of authorities. Importantly, we also predict that this two-way interaction will be qualified by political trust, effectively turning our prediction into a fairly elaborate three-way hypothesis. In other words, we predict that a certain level of political trust is necessary for the aforementioned two-way interaction between extremism and the need for security to appear. The extremists who do not trust the political system are not likely to see it as a potential security provider and, thus, will not be motivated to defend it. The reverse will be true for the extremists who have (relatively) high trust in the political system; for them, the system and its agents represent an ingroup, and those with high security needs will be especially motivated to see the system as fair and just toward all. Testing this hypothesis requires a political atmosphere that has large ideological differences between the left and the right (and thus, has extremism) and a good range in both trust and needs for security.

\section{Icelandic political landscape}

In political discussions in Iceland, both the public and the elite frequently use the terms left and right. Accordingly, research has shown that the left-right dimension is quite clearly defined in the minds of Icelandic voters and that it primarily revolves around attitudes toward capitalism and economic redistribution (Bengtsson, Hansen, Harðarson, Narud \& Oscarsson 2014). Interestingly, people on the far left and right frequently share an opposition to Iceland joining the European Union (EU). Although the concerns are slightly different for those on the left versus the right, they agree that joining the union poses a grave threat to Iceland's independence and sovereignty and that it poses a risk to the country's cultural heritage (Bailes \& Thorhallsson 2013).

Research based on election studies has shown that self-placement on the left-right scale in Iceland has remained remarkably stable since 1987 (the earliest comparable data available) with very few changes between surveys. On average, around $83 \%$ of voters have been willing to place themselves on the left-right scale ( 0 to $10 ; 0=$ left, $5=$ middle, $10=$ right), and the mean has hovered just above the center at 5.4, with around $28 \%$ of respondents picking the middle option (Thorisdottir 2012; Thorisdottir, in press).

The political system in Iceland is concisely described as a representative democracy and a parliamentary republic with a multiparty system. The pattern of political parties has, for the most part, remained the same since the 1930s, with four major parties dominating the political life. Although there have been some mergers and separations during 
this time, with the occasional new party, the four-party pattern has continued to reemerge (Kristinsson 2007). Governments have always been formed by a coalition of two or more political parties, as no single party has ever received the majority of the votes.

The Independence Party has been the only long-term party that is right of center, and due to its ability to unite all voters right of center regardless of social class, it has for decades been the largest party and a dominant player in Icelandic politics. The left has been less cohesive, with parties merging and reemerging. In 2012 (the year the data for this study were collected), and still today, the socialist Left-Green Movement is furthest to the left of the parties represented in the parliament, and the pro-EU Social Democratic Alliance closer to the middle. The Progressive Party, a former farmers' party, is a relatively small center party with outsized political power due to its ability to form coalition governments with both left- and right-wing parties. Historically, the Independence Party has received around $35 \%$ of the national vote, followed by the Social Democratic Alliance (or its predecessors) with around 25\%-30\%, with the Left-Greens and the Progressive Party each receiving 10\%-20\% (Statistics Iceland n.d. b).

At the time of this study, the government was formed by a coalition of the LeftGreen Movement and the Social Democratic Alliance, who won their largest election victory in 2009, the first election after the economic crisis in 2008. During the 12 years prior to the crisis, the government was mainly formed by a coalition of the Independence Party and the Progressive Party. As a result, they and their policies were widely blamed for the crisis, and in the 2009 election, the Independence Party suffered a dramatic defeat. The fairly stable four-party political landscape has started to shift in the wake of the political crisis following the economic one in 2008. Several smaller parties have entered the scene, two new parties (Bright Future and the Pirate Party) gained representation in the 2013 parliamentary election, and party loyalty has been markedly reduced (Önnudóttir, Schmitt \& Harðarson 2014). It has been noted that, in contrast with most neighboring countries, Iceland does not have an extremist right-wing party. Most extremist right-wing parties in Europe have been fueled by opposition to immigrants and immigration policies (Jagers \& Walgrave 2007). Although around 8\% of Iceland's population are immigrants (Statistics Iceland n.d. a), the issue has not been highly politicized. Abundant employment opportunities and perceived ethnic and value similarities between native Icelanders and the largest group of immigrants, Poles, probably goes far toward explaining this.

The economic crisis of 2008 was followed by a political crisis in many European countries. Iceland was no exception (e.g. Danielsson \& Zoega 2009) as the economic crisis hit the country with dramatic force in October of 2008. The crisis was a severe threat to people's sense of security. During the first year of the crisis, unemployment rose from $3.1 \%$ to $4.8 \%$, mortgage debt grew dramatically due to the price indexing of mortgages, and there was a sense of doom for the future of Iceland as an independent nation when government debt was reported to be 50 billion euros, seven times the Gross Domestic Product (GDP) of the country. The crisis dramatically reduced trust in elected politicians and those institutions that were strongly linked to them. Trust in 
the parliament, for example, plummeted from 42\% in 2007 to 13\% in 2009 (Datamarket n.d.). It still remains low at $18 \%$ in 2015 . The lack of trust was also evident in changes in voting behavior. In the 2010 municipality election, the political parties that were perceived as rebelling against the current system did well, whereas the establishment parties suffered defeat. This was clearly demonstrated in Reykjavík, where the semi-farcical Best Party was the undisputed winner of the election. Election turnout has also suffered in the wake of the crisis, especially in terms of the municipal election, in which turnout fell from $78.7 \%$ in 2006 to $73.4 \%$ in 2010 and all the way down to $66.5 \%$ in 2014 (Statistics Iceland 2015). Although the crisis tested people's faith in the system, the blame for the crisis was primarily put on the managers of the banks and elected politicians but not on the basic tenets and institutions of society, such as the courts or the police (Indridason, Önnudóttir, Thorisdottir \& Hardarson 2013).

Interestingly, the crisis in Iceland did not affect social trust. According to data from the European Social Survey, when people were asked whether "in general most people can be trusted," the mean trust was at $6.3(\mathrm{SD}=2.29)$ in 2004 and $6.0(\mathrm{SD}=2.12)$ in 2012.

\section{Results}

\subsection{Participants}

The data come from the sixth wave of the European Social Survey in Iceland, which was conducted in 2012. The participants were from a random probability sample of 1,431 with 752 valid interviews (53\% response rate). All interviews were conducted face to face. The ages of the participants ranged from 15 to 90 years, with a mean of 44.17 years $(\mathrm{SD}=18.69)$. There was almost an equal number of males $(\mathrm{n}=360)$ and females $(\mathrm{n}=365)$.

\subsection{Measures}

In this study, we employed a three-item scale, tapping into the perception of the procedural aspect of system fairness. Our three main independent variables were ideological extremism, the need for security, and trust, which was divided into political and general trust. The focus was on the interaction between extremism, the need for security, and political trust in predicting perceived system fairness. Other variables we adjusted for were whether the respondent voted for a government party in the last national election (2009 election, government parties: Social Democratic Alliance or Left Green Movement); the respondent's age, gender, education, and employment status; whether he or she lived in the capital; and whether he or she voted.

System fairness. To measure the perception of system fairness, we used three question pairs in which the respondents were asked to rate each question on a scale from 0-10 (therefore, an 11-point scale), first for the importance of the item for democracy and, second, for performance on those items gauged by how well they apply in Iceland. The three items were as follows: 
- That the government explains its decisions to voters

- That the rights of minority groups are protected

- That the courts treat everyone the same.

The response scales for importance ranged from $0=$ not at all important to $10=$ extremely important. For performance, the scale went from $0=$ does not apply at all to $10=$ applies completely. Table 1 shows that the three items were rated very high in importance, with a range of means from 9.2 to 9.7. Ratings for performance were much lower, ranging from 4.6 to 6.6. As can be seen in Table 1, there was no correlation between importance and performance.

A scale of system fairness was then created by computing a weighted mean of the three items for each respondent, such that for every participant, the perceived performance on each item was weighted by its perceived importance. To achieve the weighting, the 0 to 10 importance rating was rescaled to go from 0 to 1 and then multiplied by the rated performance on the item. So, for example, if a respondent assigned an importance of 5 to the protection of minority group rights and an importance of 10 to the courts treating everyone the same, the former item was weighted by 0.5 and the latter by 1 when computing the respondent's mean on the scale for system fairness. By weighing, the perception of system fairness scale takes into account that an item that is considered very important should weigh more in one's perception of system fairness compared to an item that is rated as less important.

Table 1. Importance and performance of system justification factors

\begin{tabular}{|c|c|c|c|c|c|}
\hline & \multicolumn{2}{|c|}{ Performance } & \multicolumn{2}{|c|}{ Importance } & \multirow{2}{*}{$\begin{array}{c}\text { Pearson } r \\
\text { Correlation } \\
\end{array}$} \\
\hline & Mean & St.dev. & Mean & St.dev. & \\
\hline $\begin{array}{l}\text { In country the government explains its } \\
\text { decisions to voters }\end{array}$ & 4,6 & 2,6 & 9,2 & 1,2 &,- 01 \\
\hline $\begin{array}{l}\text { In country the rights of minority groups } \\
\text { are protected }\end{array}$ & 5,9 & 2,2 & 9,2 & 1,4 & ,03 \\
\hline $\begin{array}{l}\text { In country the courts treat everyone } \\
\text { the same }\end{array}$ & 6,6 & 2,9 & 9,7 & 1,0 & ,06 \\
\hline Cronbach's alpha & \multicolumn{2}{|c|}{ 71 } & & & \\
\hline
\end{tabular}

Ideology. To measure ideological extremism, we used respondents' self-placement on the left-right scale. To capture extremism, the variable was centered around the mean and then squared. As can be seen in Figure 1, left-right placement had almost a symmetrical bell-shaped curve, with little over one-third placing themselves in the middle, about one in every 10 to the immediate left or the right of the center, and gradually fewer toward the ends $(M=5.3, S D=2.05)$. 
Figure 1. Respondents' self-placement on a left-right scale, \% ( $N=701)$

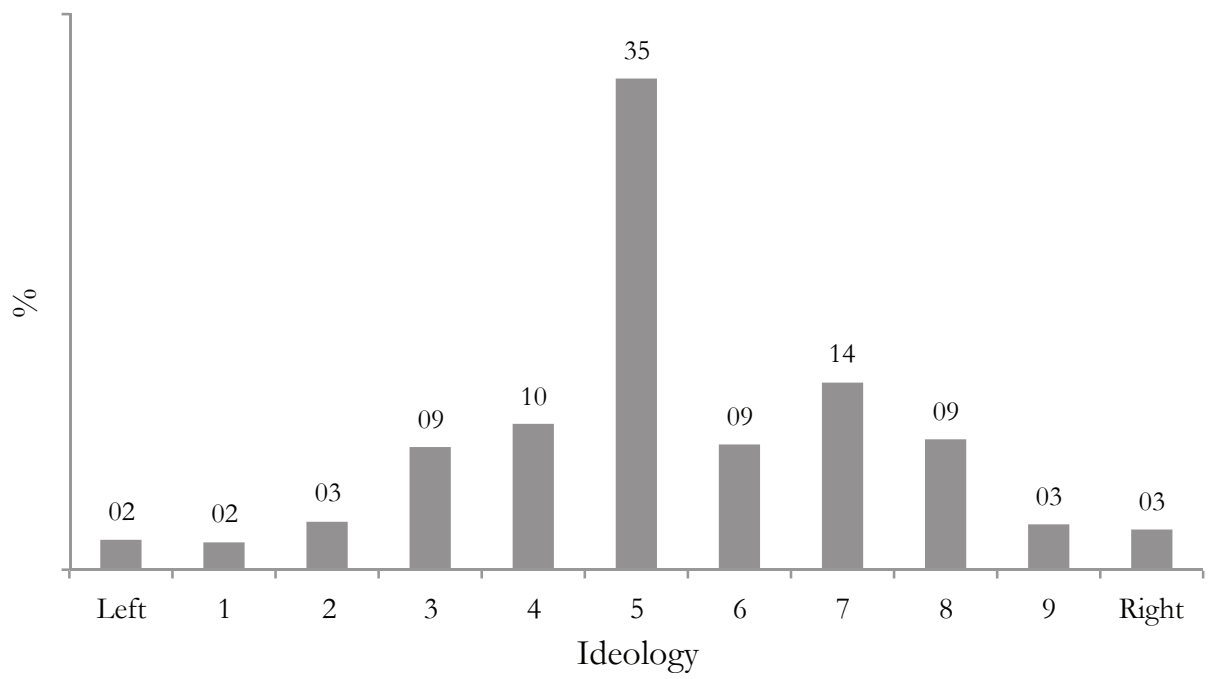

Figure 2 shows the relation between left-right self-placement and the scale of perceived system fairness. There was no apparent linear or curvilinear trend for ideological selfplacement. What is noteworthy in the figure is that the people on the left seemed to give all system fairness items a similar rating, with the exception of those on the very end of the scale, whether for people on the right there was a fairly large difference between perceived equality of treatment by the courts (high) and how well the government explains its decisions to voters (low).

Figure 2. Means of perceived system fairness by left-right self-placement

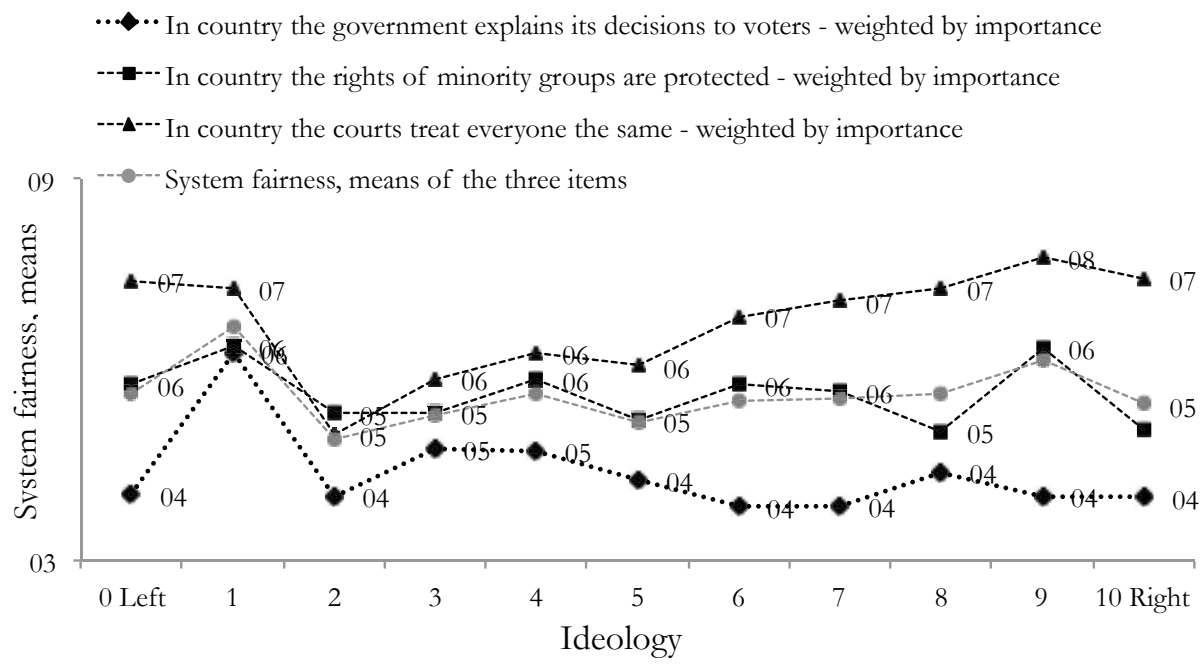


Need for security. As a measure of respondents' need for security, we used two statements from the ESS that were a part of the Schwartz (1992) Personal Values Questionnaire. The respondents were asked, on a six-point scale, how alike they were to the people described in the following two statements:

- It is important to him/her to live in secure surroundings. He/she avoids anything that might endanger his/her safety. (Personal security)

- It is important to him/her that the government ensures his/her safety against all threats. He/she wants the state to be strong so that it can defend its citizens.

(Government security)

Figure 3 shows that there was a relationship between the need for government safety and the need for personal safety. While a correlation of .30 is of medium strength, it still tells us that those who score high on personal security were more likely to score high on institutional security. In our regression models, therefore, we used a composite measure of personal and government security by taking the mean of both items for each respondent and rescaling to range from 0 (not like me at all) to 1 (very much like me) to simplify the interpretation of the results. Figure 4 shows the relationship between the need for security and left-right placement. There seems to be a slight curvilinear trend, where those furthest to the left and the right were more likely to score high on the need for security compared to those in the middle.

Figure 3. Need for security; personal and institutional. Pearson $r=.30^{*}$

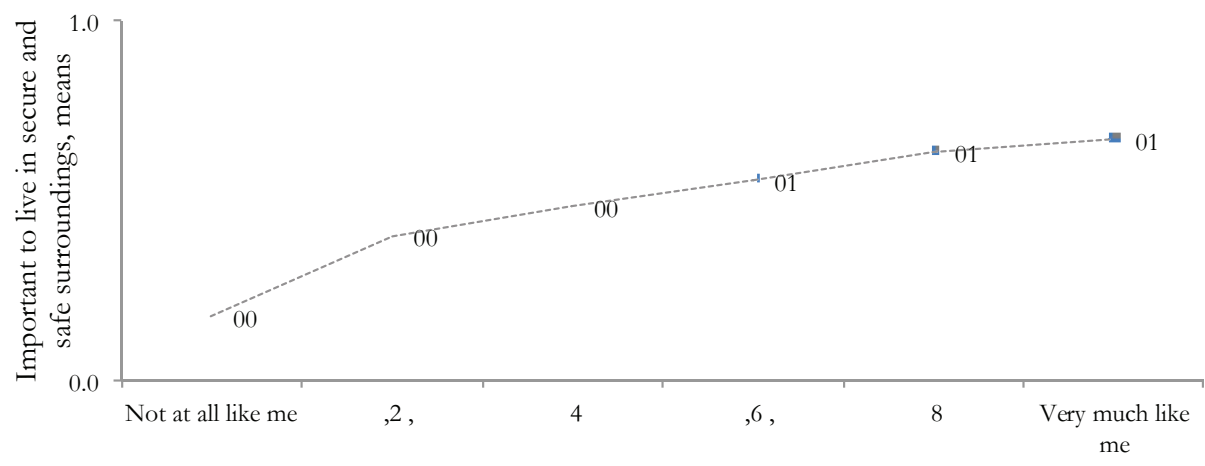

Important that government is strong and ensures safety 
Figure 4. Need for security and left-right self-placement

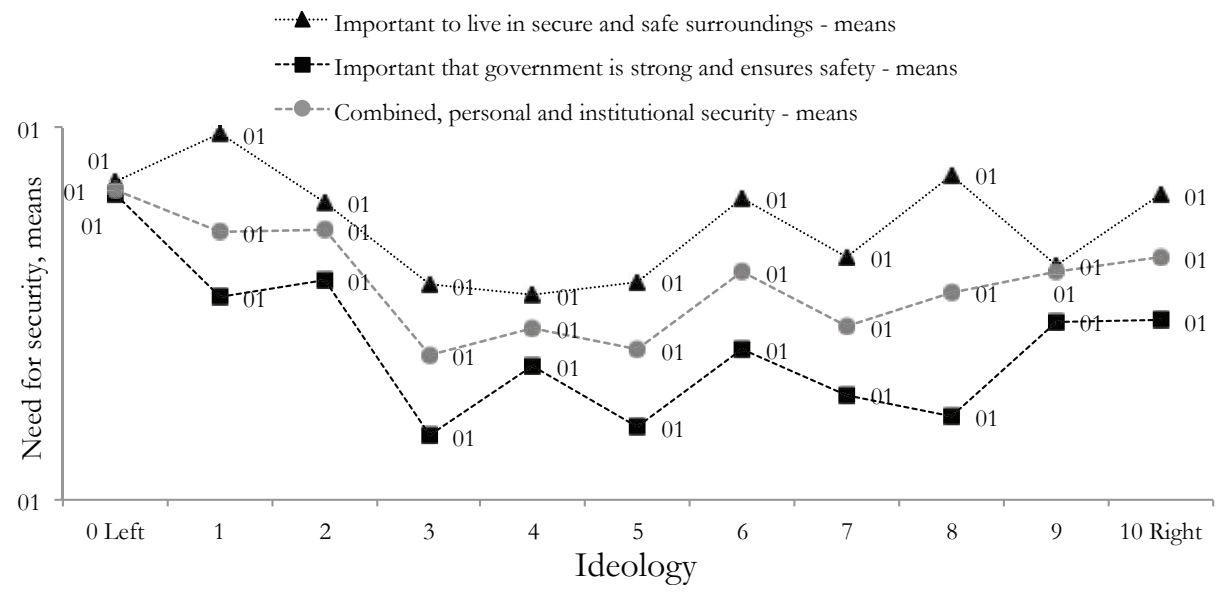

Political trust. Political trust was measured with three questions asking about trust in the parliament, political parties, and politicians. All questions were on an 11-point scale, from 0 (no trust at all) to 10 (complete trust). The correlations between the three questions were high, with Pearson's $r$ ranging from .72 to 85, and their Cronbach's alpha was .91 (Table 2), indicating that all three of them were measuring the same latent construct. We use those three questions to calculate a scale for political trust, using respondents' means score on the three items. ${ }^{1}$

Table 2. Correlation and reliability statistics for trust for parliament, political parties, and politicians

$\begin{array}{ccc}\text { Trust in } & \text { Trust in } & \text { Trust in } \\ \text { parliament } & \text { political parties } & \text { politicians }\end{array}$

\begin{tabular}{l}
\hline Trust in parliament \\
Trust in political parties $.72^{* * *}$ \\
Trust in politicians $.75^{* * *}, 91$ \\
\hline Cronbach's alpha for the three trust items: \\
\hline
\end{tabular}

*Correlation entries are Pearson's $r$

Figure 5 shows the means, from left to right respondents' self-placement, for each of the three items, as well as the mean scale for political trust. Although there was no apparent trend from left to right for the composite measure of political trust, ${ }^{2}$ the differences 
between the three measures of political trust were larger on the left compared to the right. This may have been caused by the fact that at the time of the survey, the incumbent government was left-wing (Social Democratic Alliance and Left-Green Movement). Thus, left-wing voters may have expressed greater trust for the parliament because their party was in government. We control for this possible bias, caused by the fact that the voters' preferred party is in government-referred to as a winners-and-losers' effect (e.g. Holmberg 1999) - by including in our models whether the respondents' preferred party is an incumbent government party.

Figure 5. Political trust and left-right self-placement

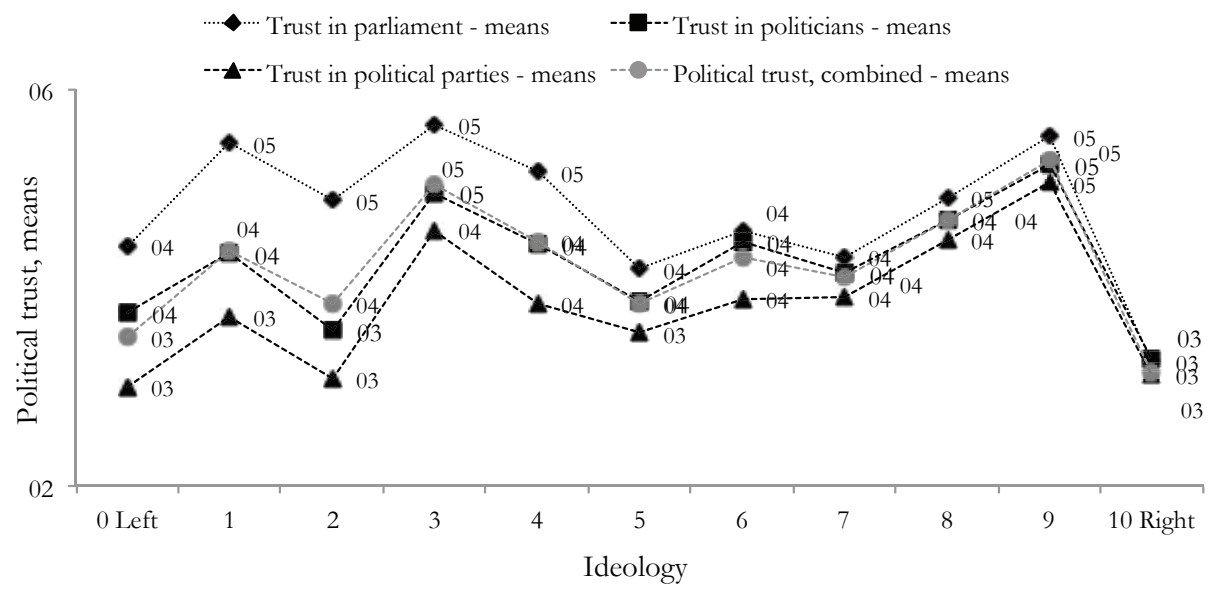

Because we hypothesized about a three-way interaction between extremism, the need for security, and political trust, we also examined the bivariate relation between the need for security and political trust (Figure 6). The pattern in the figure indicates a slight curvilinear trend, where those that had a high and low need for security scored lower on political trust compared to other respondents.

Adjustment variables. To adjust for a more general tendency to trust others, we adjusted for social trust, measured by the question asking whether most people can be trusted or whether one cannot be too careful, with a response scale from 0 (you cannot be too careful) to 10 (most people can be trusted). ${ }^{3}$

As previously mentioned, we also adjusted for whether the respondent voted for a government party or not. Other variables that have been found to predict system support (e.g., Anderson and Singer 2008), and which we included in the model, were the respondent's age, gender, education, employment status; whether he or she lives in the capital area; and his or her electoral participation. 
Figure 6. Political trust and the need for security ${ }^{4}$

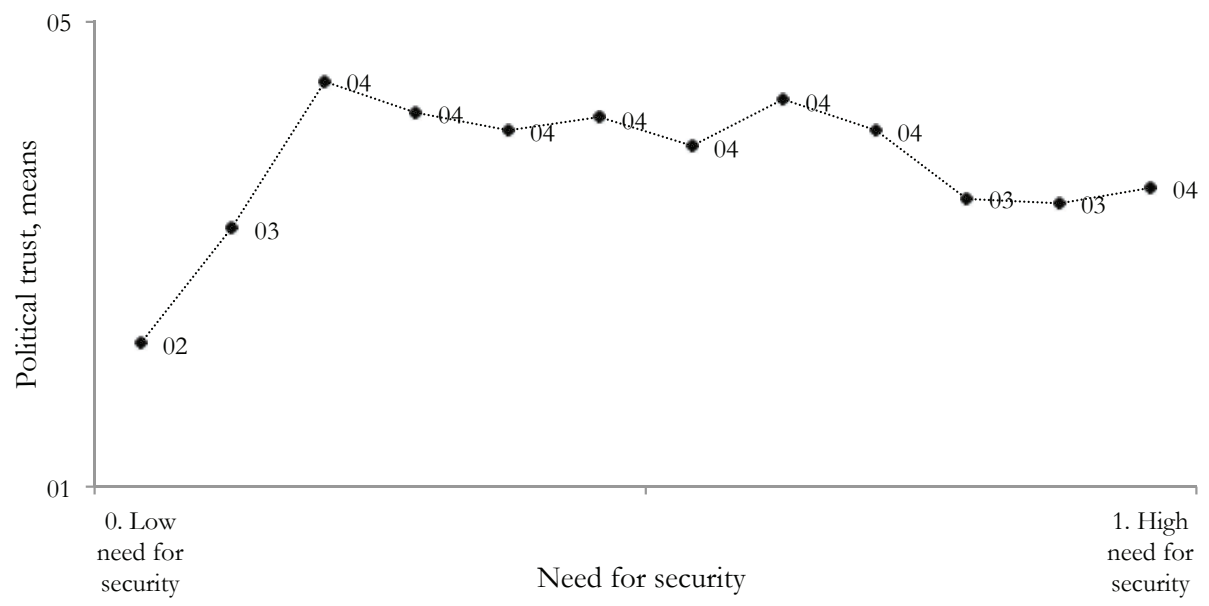

\subsection{Regression models}

To test our hypotheses that a three-way interaction between ideological extremism, needs for security, and political trust will predict perceived system fairness, we ran an OLS regression in four steps (Table 3).

In step one, when entering only the main effects of the need for security and ideology (both linear and curvilinear to capture the extremism effect) in addition to adjustment variables, none were statistically significant. The trust variables were added in step two, both resulting in a positive significant effect on perceived system fairness. In step three, we added all the two-way interaction effects, but the main test of the hypothesis of the study was the three-way interaction between left-right extremism, the need for security, and political trust added in the fourth and final step, to which we now turn. 


\section{STJÓRNSÝSLA}

Table 3. Perception of system fairness, OLS regressions

\begin{tabular}{|c|c|c|c|c|}
\hline & $\begin{array}{c}1 \text { step } \\
\text { B } \\
\text { (std.err.) }\end{array}$ & $\begin{array}{c}2 \text { step } \\
\text { B } \\
\text { (std.err.) }\end{array}$ & $\begin{array}{c}3 \text { step } \\
\text { B } \\
\text { (std.err.) }\end{array}$ & $\begin{array}{c}4 \text { step } \\
\text { B } \\
\text { (std.err.) }\end{array}$ \\
\hline Left-right centered & $\begin{array}{c}, 05 \\
(.049)\end{array}$ & $\begin{array}{c}, 05 \\
(.043)\end{array}$ & $\begin{array}{c}, 24 \\
(.172)\end{array}$ & $\begin{array}{c}, 18 \\
(.352)\end{array}$ \\
\hline Left-right extremism (curvilinear) & $\begin{array}{c}, 02 \\
(.015)\end{array}$ & $\begin{array}{c}, 01 \\
(.013)\end{array}$ & $\begin{array}{c}, 04 \\
(.058)\end{array}$ & $\begin{array}{c}.21+ \\
(.109)\end{array}$ \\
\hline Need for security (government) & $\begin{array}{c}-, 04 \\
(.437)\end{array}$ & $\begin{array}{c}.71+ \\
(.393)\end{array}$ & $\begin{array}{c}-, 82 \\
(.898)\end{array}$ & $\begin{array}{c}, 24 \\
(1.027)\end{array}$ \\
\hline Political trust & & $\begin{array}{l}.35 * * * \\
(.042)\end{array}$ & $\begin{array}{c}, 02 \\
(.135)\end{array}$ & $\begin{array}{c}, 22 \\
(.165)\end{array}$ \\
\hline General trust & & $\begin{array}{l}.24^{* * *} \\
(.043)\end{array}$ & $\begin{array}{l}.24^{* * *} \\
(.043)\end{array}$ & $\begin{array}{l}.24^{* * *} \\
(.043) \\
\end{array}$ \\
\hline Security*political trust & & & $\begin{array}{c}.47^{*} \\
(.197)\end{array}$ & $\begin{array}{c}, 17 \\
(.244)\end{array}$ \\
\hline Left-right centered*security & & & $\begin{array}{c}-, 13 \\
(.200)\end{array}$ & $\begin{array}{c}-, 07 \\
(.472)\end{array}$ \\
\hline Left-right curv. *security & & & $\begin{array}{c}-, 07 \\
(.071)\end{array}$ & $\begin{array}{l}-.30 * \\
(.148)\end{array}$ \\
\hline Left-right centered*political trust & & & $\begin{array}{c}-, 03 \\
(.018)\end{array}$ & $\begin{array}{c}-, 02 \\
(.075)\end{array}$ \\
\hline Left-right curv. ${ }^{*}$ political trust & & & $\begin{array}{c}, 00 \\
(.006)\end{array}$ & $\begin{array}{l}-.04+ \\
(.025)\end{array}$ \\
\hline Left-right cen. ${ }^{*}$ need for sec. ${ }^{*}$ political trust & & & & $\begin{array}{c}, 01 \\
(.104)\end{array}$ \\
\hline Left-right curv. ${ }^{*}$ need for sec. ${ }^{*}$ political trust & & & & $\begin{array}{c}.07 * \\
(.035)\end{array}$ \\
\hline Age & $\begin{array}{c}.01^{*} \\
(.006)\end{array}$ & $\begin{array}{c}.01^{*} \\
(.005)\end{array}$ & $\begin{array}{c}.02 * \\
(.005)\end{array}$ & $\begin{array}{l}.02 * * \\
(.005)\end{array}$ \\
\hline Education (reference $=$ primary) & & & & \\
\hline Secondary & $\begin{array}{c}, 47 \\
(.325)\end{array}$ & $\begin{array}{c}, 26 \\
(.289)\end{array}$ & $\begin{array}{c}, 24 \\
(.290)\end{array}$ & $\begin{array}{c}, 29 \\
(.290)\end{array}$ \\
\hline Vocational & $\begin{array}{c}-, 11 \\
(.254)\end{array}$ & $\begin{array}{c}-, 16 \\
(.225)\end{array}$ & $\begin{array}{c}-, 18 \\
(.226)\end{array}$ & $\begin{array}{c}-, 20 \\
(.225)\end{array}$ \\
\hline University & $\begin{array}{c}.48^{*} \\
(.231)\end{array}$ & $\begin{array}{c}, 13 \\
(.208)\end{array}$ & $\begin{array}{c}, 09 \\
(.208)\end{array}$ & $\begin{array}{c}, 11 \\
(.208)\end{array}$ \\
\hline Unemployed & $\begin{array}{c}, 30 \\
(.585)\end{array}$ & $\begin{array}{c}, 33 \\
(.519)\end{array}$ & $\begin{array}{c}, 36 \\
(.517)\end{array}$ & $\begin{array}{c}, 42 \\
(.516)\end{array}$ \\
\hline Capital area & $\begin{array}{l}-.32+ \\
(.187)\end{array}$ & $\begin{array}{c}-.47 * * \\
(.167)\end{array}$ & $\begin{array}{c}-.50 * * \\
(.166)\end{array}$ & $\begin{array}{l}-.51^{* *} \\
(.166)\end{array}$ \\
\hline Male & $\begin{array}{c}, 22 \\
(.182)\end{array}$ & $\begin{array}{l}.48^{* *} \\
(.164)\end{array}$ & $\begin{array}{l}.45^{* *} \\
(.164)\end{array}$ & $\begin{array}{l}.44^{* *} \\
(.164)\end{array}$ \\
\hline Voted for incumbent government party & $\begin{array}{c}, 05 \\
(.215)\end{array}$ & $\begin{array}{c}-, 08 \\
(.191)\end{array}$ & $\begin{array}{c}-, 07 \\
(.191)\end{array}$ & $\begin{array}{c}-, 04 \\
(.190)\end{array}$ \\
\hline Voted & $\begin{array}{c}, 41 \\
(.301) \\
\end{array}$ & $\begin{array}{c}, 20 \\
(.268) \\
\end{array}$ & $\begin{array}{c}, 29 \\
(.269) \\
\end{array}$ & $\begin{array}{c}, 29 \\
(.269) \\
\end{array}$ \\
\hline Constant, sig.value &, 000 &, 003 & 001 &, 025 \\
\hline R sq. & ,03 & ,24 & ,26 & ,26 \\
\hline R sq. change, sig. value & 210 &, 000 &, 060 & ,095 \\
\hline $\mathrm{N}$ & 508 & & & \\
\hline
\end{tabular}

*Response variable is 'perception of system fairness'. Significane levels: $+p<.1,{ }^{*} p<.05,{ }^{* *} p<.01,{ }^{* * *} p<.001$. 
Figures 7 and 8 display the three-way interaction, or, more precisely, how the two-way interaction between extremism and the need for security depends on the level of political trust. Figure 7 shows those who report a low level of political trust ( -1.5 st.dev.) for different levels on the need for security $(-/+1.5$ st.dev.) and extremism. Figure 8 shows the same, but for high trust. Looking first at the two-way interaction when trust was low (Figure 7), it is apparent that extremism had the opposite effects on perceived system fairness, depending on whether people had a low (light gray line) or high need (dark gray line) for security. When the need for security was low and political trust was low, political extremists perceived the system as more fair compared to moderates. This was especially true for extremists on the right, which possibly indicates that this pattern is mostly replicating the well-known finding that people on the right have a stronger tendency than those on the left to perceive the system as fair and just. Interestingly, when the need for security was high and trust was low, extremists perceived the system as less fair compared to moderates. This could indicate that those extremists who have a high need for security but low trust in the political system are especially disillusioned by the system because they do not perceive it to provide them with the security and certainty they are motivated to find. This is supported by the findings for bigh political trust reported in Figure 8 . There, displayed by the dark gray line, we see a reverse pattern for extremists who had a high need for security but high political trust. This line shows that political extremists who have a high need for security and also trust the political system are more likely to perceive the system as fair, thereby confirming the main hypothesis of the study. The hypothesis receives added support by the fact that the average predicted value for system fairness among political extremists is by far the highest we see in the data, supporting the reasoning that this group of people may be especially motivated to perceive the system as fair because it serves as an important source of security and certainty. For people who are high on trust but low on security, there seems to be a weak relationship with ideology, as shown by the light-gray line in Figure 8. 
Figure 7. System fairness and extremism*need for security*political trust - Low trust

- $=$ - Low trust ( -1.5 st.dev.)*Low need for security ( -1.5 st.dev.)

.... Low trust ( -1.5 st.dev.) $*$ High need for security (+1.5 st.dev)

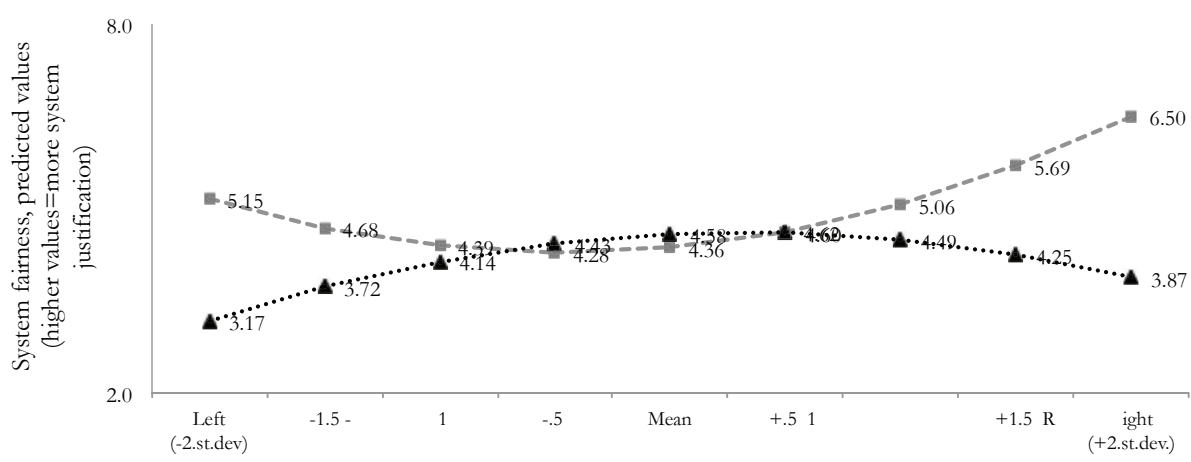

Ideology

Figure 8. System fairness and extremism*need for security*political trust - High trust

$$
\begin{aligned}
& \text { - }- \text { High trust (+1.5 st.dev.)*Low need for security ( }-1.5 \text { st.dev. }) \\
& \text { … } \text {. High trust }(+1.5 \text { st.dev. }) * \text { High need for security }(+1.5 \text { st.dev. })
\end{aligned}
$$

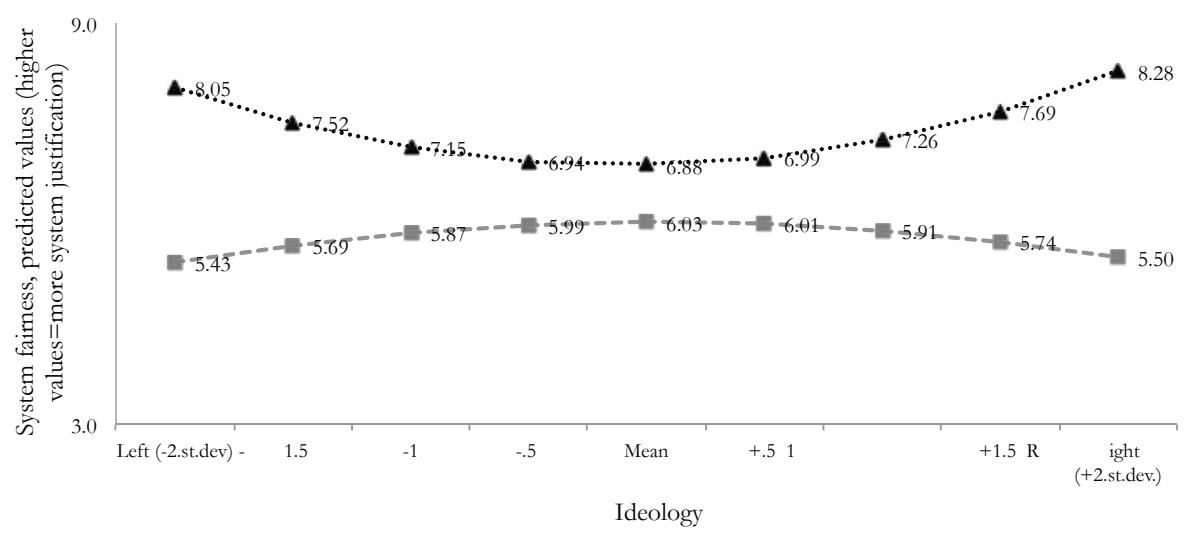




\section{Discussion}

This study has been the first to show that a curvilinear relationship exists between political orientation and perceived system fairness when certain psychological conditions are met. Namely, when those on the far ends of the political spectrum have both relatively high political trust and a strong need for security, they become especially likely to perceive the system as fair. This was demonstrated using nationally representative data from Iceland which were collected in 2012, a few years after a dramatic economic crisis that shook citizens' sense of security and their trust in authorities. The results held when adjusted for social trust, whether the respondent had voted for a governmental party, and a few other demographic variables previously shown to matter in similar analyses.

The findings speak directly to a body of literature that has emerged in the last few years on the psychology of extremism (Fernbach, Rogers, Fox \& Sloman 2013; van Prooijen, Krouwel, Boiten \& Eendebak 2015; Toner, Leary, Asher \& Jongman-Sereno 2013). This literature has demonstrated that political extremists on the left and right have some psychological characteristics in common that differentiate them from political moderates. This does not mean that the "rigidity of the right" hypothesis is necessarily false. It could mean that although people who are motivated to manage uncertainty and threat are more likely to find "elective affinities" with the right-wing or conservative ideology (Jost, Federico \& Napier 2009), they may also do so on the left, especially in societies in which left-wing and right-wing ideologies reach far from the center.

Espousing political views outside the mainstream has psychological antecedents and consequences. Whether your views are on the right because you strongly believe in the laws of the free market or on the left because you would like much more radical measures put in place to guarantee equality of income, being drawn to a comprehensive and internally consistent ideological system may, in both cases, partially meet a need for certainty and security. What is very probable, however, is that people with heightened needs for security are looking for ways to meet their security and certainty needs beyond what an ideology can offer. These needs will presumably be fulfilled in different ways on the left and right. A high need for security in the left domain may manifest itself in the desire for a strong welfare system that protects and provides for all citizens, regardless of their capabilities and social standing (Malka \& Soto 2014). On the right, however, the need for safety will more likely pertain to security from crime, terrorism, and other forms of disturbances to the social order (Jost et al. 2003).

Even if not a part of what was hypothesized in this study, it is noteworthy that both political trust and the need for security had direct positive effects on perceived system fairness. This indicates that those who express greater political trust and have a higher need for security are more likely to perceive the system as fair. The finding that for political extremes, the effect of the need for security on system fairness is conditioned by political trust further underlines the importance of political trust as a stabilizing factor both for the political extremes and for democracy. This is even more important given that the extremes are more likely to experience represenational exclusion, and under 
these circumstances, having relatively high political trust offers an assurance that the authorities will not abuse their power.

The relationship of interest in this study is admittedly a complicated one as it describes a three-way interaction. Future studies on the topic would ideally be able to further explore the psychological factors that extremists have in common, especially as they pertain to the needs for security and certainty. In this study, we followed researchers within political psychology and operationalized political extremism as self-reported distance from the midpoint on the one-dimensional left-right scale (e.g., van Prooijen, Krouwel, Boiten \& Eendebak 2015). Of course, this is a highly simplified measure of ideological extremism as it is relative and tells us nothing about the contents of the ideology, political sophistication, or strength of attitudes. For our understanding of political extremism to advance, an imminent next step in this line of work is to dive into the contents of the ideologies held by people on the extreme ends of the scale. The dependent measure of perceived system fairness should also be scrutinized. Our method of constructing a three-item scale of system fairness based on how well people think the government explains its decisions to voters, that the rights of minority groups are protected, and that the courts treat everyone the same resulted in an acceptable alpha but not an exceptionally high one. We also saw in Figure 2 that the level of agreement on performance on those items (weighted by importance) differed substantially across the left-right continuum in a somewhat unpredictable fashion. This may suggest that the items are not equally good measures of system fairness for people of all political leanings.

One of the other questions that remain to be answered is whether the three-way interaction between ideological extremism, the need for security, and political trust is particular to Iceland. More narrowly, perhaps the results would only emerge in Iceland due to the peculiar dynamics set in motion following the economic and political crisis of 2008. A counter argument would be that there is no obvious reason to assume that the crisis affected those on the ideological extremes, concerning their need for security, differently compared to the moderates. Furthermore, there are no indicators that Icelanders have become more polarised after the crash. What we see is that people have lost faith in representative institutions, such as the parliament and traditional political parties, a phenomenon that is hardly unique to Iceland. In Iceland, this loss of trust and legitimacy has opened up space for new parties to gain representation. These new parties do not subscribe to extreme ideologies but are politically moderate (Bright Future) or have taken pains to define themselves outside of the left-right dimension (Pirate Party). Whether we will find the same relationship as has been reported here in other countries is an empirical question that is waiting to be tested. Such a replication will be relatively straightforward as the data employed in this study, from the sixth wave of the European Social Survey, are available from close to 30 European countries. In pursuing this question, it would probably be necessary to take into account the different capabilities of states to provide welfare and safety for their citizens. To sum up, in this 
paper, we have established the importance of taking into account the level of political trust when examining the effect of the political extremes and their need for security on system fairness. Those who place themselves on the extremes and have a high need for security only perceive the system as fair when they trust it. In this way, political trust can compensate for the loss of representation on the extremes.

This research is part of the Icelandic Power and Democracy Research Project (2014-2017). For further information on the research project see: www.vol.hi.is

\section{Notes}

1 Pearson $\mathrm{r}$ correlation between system fairness and political trust is .41.

2 A total of 19 respondents place themselves on the far right end point of 10, and 23 placed themselves at 9. A total of 28 respondents placed themselves on the far left, 14 on 0 , and 14 on 1 .

3 General trust correlates modestly with the three items on political trust, ranging from Pearson $\mathrm{r}=$ .27 (with political parties) to .35 (with parliament).

4 The number of reponses from 0 to 0.2 (first three points) are $26(0=2,0.1=8$ and $0.2=15$ ). Combining these three points results in a mean score of 3.9 on political trust.

\section{References}

Adorno, T. W., Frenkel-Brunswik, E., Levinson, D. J. and Sanford, R. N. (1950). The authoritarian personality. New York: Harper.

Altemeyer, B. (1998). "The other "authoritarian personality"”. Advances in Experimental Social Psychology 30, 48-92.

Anderson, C. J., and Singer, M. M. (2008). "The sensitive left and the impervious right: multilevel models and the politics of inequality, ideology, and legitimacy in Europe", Comparative Political Studies 41, 564-599.

Bailes, A. J.K. and Thorhallsson, B. (2013). Iceland and Europe: Drifting Further Apart? Finnish Institute of International Affairs Briefing Paper no 139 (2013). Retrieved 30 October 2015 from: http://www. fiia.fi/en/publication/360/iceland_and_europe/(accessed October 20, 2015).

Bengtsson, A., Hansen, K., Harðarson, Ó. P., Narud, H. M., and Oscarsson, H. (2014). The Nordic voter: myths of exceptionalism. London: ECPR Press.

Brandt, Evans and Crawford. (2014). "The unthinking or confident extremist? Political extremists are more likely than moderates to reject experimenter-generated anchors", Psychological Science 26(2), 189-202.

Danielsson, J. and Zoega, G. (2009). The Collapse of a Country. Reykjavik: Institute of Economic Studies.

Datamarket. (n.d.). “Traust til stofnanna skv. Djóðarpúlsi Gallup”. Retrieved 22 Ocotber 2015 from: https://datamarket.com/data/set/1wb6/traust-til-stofnana-skv-thjodarpulsi-capacent\#!ds=$1 \mathrm{wb} 6 ! 1 \mathrm{xyh}=1 \&$ display $=$ line.

De Cremer, D. and Tyler, T. R. (2007). "The effects of trust in authority and procedural fairness on cooperation”, Journal of Applied Psychology 92(3), 639.

Diamond, L. (1999). Developing democracy: Toward consolidation. Baltimore: Johns Hopkins University Press.

Fernbach, P. M., Rogers, T., Fox, C. R. and Sloman, S. A. (2013). "Political extremism is supported by an illusion of understanding", Psychological Science 24, 939-946.

Grönlund, K. and Setälä, M. (2007)."Political trust, satisfaction and voter turnout”, Comparative European Politics 5(4), 400-422.

Hardin, R. (2002). "The crippled epistemology of extremism”, in A. Breton, G. Galeotti, P. Salmon, \& R. Wintrobe (eds.), Political extremism and rationality (pp. 3-22). Cambridge: Cambridge University Press. 
Hogg, M. A., Kruglanski, A., and Bos, K. (2013). "Uncertainty and the roots of extremism", Journal of Social Issues 69(3), 407-418.

Holmberg, S. (1999). "Down and down we go: Political trust in Sweden", in P. Norris (ed.), Critical citizens: Global support for democratic governance (pp. 103-122). Oxford: Oxford University Press.

Hooghe, M., Marien, S. and Pauwels, T. (2011). "Where do distrusting voters turn if there is no viable exit or voice option? The impact of political trust on electoral behaviour in the Belgian regional elections of June 2009 1", Government and Opposition 46(2), 245-273.

Indridason, I. H., Önnudóttir, E. H., Thorisdottir, H. and Hardarson, O. T. (2013). "Re-electing the culprits: Election in Iceland in Times of Economic Recession", paper presented at The 2013 EUDO Dissemination Conference: Elections in Europe in Times of Crisis. Florence, Italy, 28-29 November.

Jagers, J. and Walgrave, S. (2007). "Populism as political communication style: An empirical study of political parties' discourse in Belgium”, European Journal of Political Research, 46, 319-345.

Jost, J. T. and Thompson, E. P. (2000). "Group-based dominance and opposition to equality as independent predictors of self-esteem, ethnocentrism, and social policy attitudes among African Americans and European Americans", Journal of experimental social psychology 36(3), 209-232.

Jost, J. T., Banaji, M. R. and Nosek, B. A. (2004). "A decade of system justification theory: Accumulated evidence of conscious and unconscious bolstering of the status quo", Political Psychology, 25(6), 881919.

Jost, J. T., Federico, C. M. and Napier, J. L. (2009). "Political ideology: Its structure, functions, and elective affinities", Annual review of psychology, 60, 307-337.

Jost, J. T., Glaser, J., Kruglanski, A. W. and Sulloway, F. J. (2003). "Political conservatism as motivated social cognition”, Psychological Bulletin, 129(3), 339.

Kristinsson, G. H. (2007). Íslenska stjórnkerfio. Reykjavik: Háskólaútgáfan.

Kruglanski, A. W., Pierro, A., Mannetti, L., and De Grada, E. (2006). "Groups as epistemic providers: need for closure and the unfolding of group-centrism", Psychological Review, 113(1), 84.

Lammers, J. and Proulx, T. (2013). "Writing autobiographical narratives increases political conservatism", Journal of Experimental Social Psychology, 49(4), 684-691.

Lind, E. A. and Tyler, T. R. (1992). "A relational model of authority in groups", Advances in Experimental Social Psychology, 25, 115-92.

Lühiste, K. (2006). "Explaining trust in political institutions: Some illustrations from the Baltic states", Communist and Post-Communist Stud"ies, 39(4), 475-496.

Malka, A., Soto, C., Inzlicht, M. and Lelkes, Y. (2014). "Do needs for security and certainty predict cultural and economic conservatism? A cross-national analysis", Journal of Personality and Social Psychology, 106(6), 1031.

McClosky, H. and Chong, D. (1985). "Similarities and differences between left-wing and right-wing radicals", British Journal of Political Science, 15, 329-363.

Napier, J. L. and Jost, J. T. (2008). "Why are conservatives happier than liberals? ”, Psychological Science, 19(6), 565-572.

Newton, K. (1999). "Social and political trust in established democracies", in P. Norris (ed.), Critical citizens: Global support for democratic government (pp. 185-186). Oxford: Oxford University Press.

Norris, P. (2011). Democratic deficit: Critical citizens revisited. Cambridge: Cambridge University Press.

Önnudóttir, E. H., Schmitt, H. and Harðarson, Ó. P. (2014). "Voting Before and in a Crisis an Economic and Political Crisis: The Icelandic Elections 2007and 2009", paper presented at the 72nd Annual Conference of Midwest Political Science Association, 3-6 April. Chicago.

Palfrey, T. R. and Poole, K. T. (1987). "The relationship between information, ideology, and voting behavior", American Journal of Political Science 31(3), 511-530.

Roccato, M., Vieno, A. and Russo, S. (2013). "Criminal victimisation fosters conservatism among people living in areas with high unemployment rates: A multilevel longitudinal study", European Journal of Social Psychology 43(6), 585-592. 
Schlenker, B. R., Chambers, J. R. and Le, B. M. (2012). "Conservatives are happier than liberals, but why? Political ideology, personality, and life satisfaction", Journal of Research in Personality 46(2), 127-146.

Schwartz, S. H. (1992). "Universals in the content and structure of values: Theoretical advances and empirical tests in 20 countries", in M. Zanna (ed.), Advances in experimental social psychology (Vol. 25, pp. 1-65). New York: Academic Press.

Sidanius, J. (1984). "Political interest, political information search, and ideological homogeneity as a function of sociopolitical ideology: A tale of three theories", Human Relations 37(10), 811-828.

Sidanius, J. (1988). "Political sophistication and political deviance: A structural equation examination of context theory", Journal of Personality and Social Psychology 55(1), 37.

Sidanius, J. and Lau, R. R. (1989). "Political sophistication and political deviance: A matter of context", Political Psychology 10, 85-109.

Sidanius, J. and Pratto, F. (1999). Social dominance: An intergroup theory of social hierarchy and oppression. Cambridge: Cambridge University Press.

Statistics Iceland. (n.d. a.) "Population - key figures 1703-2015". Retrieved 20 October 2015 from: http://px.hagstofa.is/pxis/pxweb/is/Ibuar/Ibuar__mannfjoldi__3_bakgrunnur__Uppruni/ MAN43000.px/.

Statistics Iceland. (n.d. b). "Results of General Elections to the Althingi 1963-2013”. Retrieved on 21 October 2015 from: http://px.hagstofa.is/pxen/pxweb/en/Ibuar/Ibuar_kosningar_althingi_ althurslit/KOS02121.px.

Statistics Iceland. (n.d. c). "Participation in local government eletions 1938-2014". Retrieved December 12015 from http://www.statice.is/publications/publication-detail?id=55767.

Tetlock, P. E. (1986). "A value pluralism model of ideological reasoning", Journal of Personality and Social Psychology 50(4), 819.

Thorisdottir, H. (2012). "The left-right axis in the mind of Icelandic voters 1987-2009”, Icelandic Revien of Politics and Administration 2, 199-220.

Thorisdottir, H. (in press). "The left-right landscape over time: The view from a Western-European multi-party democracy" in Graham, J. and Valdesolo, P (eds.); Bridging the ideological divide. London: Blackwell

Toner, K., Leary, M. R., Asher, M. W. and Jongman-Sereno, K. P. (2013). "Feeling superior is a bipartisan issue extremity (not direction) of political views predicts perceived belief superiority", Psychological Science 24, 2454-2462.

Tyler, T. R. (1990). Why people obey the law: Procedural justice, legitimacy, and compliance. New Haven, CT: Yale University Press.

Tyler, T. R. (2000). "Social justice: Outcome and procedure”, International Journal of Psychology, 35(2) 117-125.

Tyler, T. R. and Blader, S. L. (2000). Cooperation in groups: Procedural justice, social identity, and behavioral engagement. Philadelphia, PA: Psychology Press.

Tyler, T. R. and Blader, S. L. (2003). "The group engagement model: Procedural justice, social identity, and cooperative behavior", Personality and Social Psychology Review 7(4), 349-361.

Tyler, T. R. and Huo, Y. (2002).Trust in the law: encouraging public cooperation with the police and courts through. New York: Russell Sage Foundation.

Van den Bos, K., Lind, E. A., Vermunt, R. and Wilke, H. A. (1997). "How do I judge my outcome when I do not know the outcome of others? The psychology of the fair process effect", Journal of Personality and Social Psychology 72(5), 1034-1046.

Van Ham, C. and Thomassen, J. (2014). "The legitimacy crisis of representative democracy: Myth or reality?", paper presented at the 72th Annual MPS A Conference, Chicago, April 3-6, 2014.

Van Hiel, A. and Mervielde, I. (2003). "The measurement of cognitive complexity and its relationship with political extremism", Political Psychology 24(4), 781-801.

Van Lange, P. A., Bekkers, R., Chirumbolo, A. and Leone, L. (2012). "Are conservatives less likely to be 
prosocial than liberals? From games to ideology, political preferences and voting", European Journal of Personality 26(5), 461-473.

Van Proojien, J. W., Krouwel, A. P., Boiten, M. and Eendebak, L. (2015). "Fear among the extremes: how political ideology predicts negative emotions and outgroup derogation", Personality and Social Psychology Bulletin 41(4), 485-497.

Van Prooijen, J. W., Krouwel, A. and Pollet, T. (2015). "Political extremism predicts belief in conspiracy theories", Social Psychological and Personality Science 6(5), 570-578.

Wilson, G. D. and Patterson, J. R. (1968). "A new measure of conservatism", British Journal of Social and Clinical Psychology 7(4), 264-269.

Zaller, J. (1992).The nature and origins of mass opinion. Cambridge: Cambridge University Press. 
